\title{
Evaluation of Acute Aortic Dissections in the Emergency Department: A Retrospective Study.
}

\author{
Acil Serviste Akut Aort Diseksiyonlarının Değerlendirilmesi: Geriye Dönük Çalı̧ma
}

Department of Emergency Medicine, Faculty of Medicine, Eskisehir Osmangazi University, Eskisehir, Turkey

Department of Cardiovascular Surgery Faculty of Medicine, Eskisehir Osmangazi University, Eskisehir, Turkey
${ }^{1}$ Mustafa Emin Canakci, ${ }^{1}$ Omer Erdem Sevik, ${ }^{1}$ Yagmur Ay, ${ }^{1}$ Engin Ozakin, ${ }^{2}$ Aykut Sahin, ${ }^{1}$ Nurdan Acar Abstract

Aortic dissection (AD) is a life-threatening emergency that has a mortality rate of around $27 \%$ even when optimal conditions are met. Atypical process of the disease which can mimic other critical conditions makes it harder to diagnose. The study aimed to determine Emergency department presentations and factors that influence the diagnostic process, emergency department, and in-hospital mortalities of acute AD patients. This study is a single-centered retrospective observational study. Patients with ICD-10 codes for AD in their digital files were analyzed. Patients were categorized into Stanford Type A or B dissections according to their computerized tomography scans. Also, the patients were compared in terms of survival. Eighty-eight patients had an acute AD and the mean age was $61,90 \pm 12,67$ years. According to Stanford Classification, 68 patients had Type A dissection. Altered mental status and syncope were detected more in Type $\mathrm{A}(\mathrm{p}=0.003$ and $\mathrm{p}=0.001)$. Bilateral arm blood pressure readings differential was more in Type A ( $p=0.007)$. Blood products were used and endotracheal intubation was performed more in Type $A(p=0.002$ and $p=0.005)$. Patients who had bilateral arm blood pressure differential had 3.5-fold, who had developed cardiac arrest in ED had 5.07-fold, who got blood product transfusions had 5.41-fold more risk of death. [OR:3.50; (CI 95\% 1.36-8.94) p=0.009, OR: 5.07; (CI 95\% 1.1821.39) $\mathrm{p}=0.027$ and OR: 5.41 ; (CI 95\% 1.97-14.78) $\mathrm{p}=0.001$ respectively]. The mortality rates in ED and in-hospital were $12.5 \%$ and $61.4 \%$ respectively. Aortic dissections will stay as important clinical conditions which management in ED is crucial. Atypical presentation of $\mathrm{AD}$ and the nature of the disease cause delays in diagnoses. $\mathrm{AD}$ should be considered in the foreground in patients presenting with syncope and altered mental status. When there is a clinical suspicion the scan of the aorta with computerized tomography must be ordered rapidly.

Keywords: Aortic dissection; Emergency department; Stanford classification

\section{Özet}

Aort diseksiyonu (AD), optimal koşullar sağlandığında bile mortalitesi yaklaşık \%27 olan hayatı tehdit eden bir acil durumdur. Hastalığın diğer kritik durumları taklit edebilen atipik süreci tanı koymayı zorlaștırmaktadır. Bu çalıșmanın amacı, akut aort diseksiyonu hastalarının acil servis başvurularını ve tanı sürecini, acil servis ve hastane içi ölümleri etkileyen faktörleri belirlemektir. Bu çalışma tek merkezli retrospektif gözlemsel bir çalışmadır. Dijital dosyalarında AD için ICD-10 kodları bulunan hastalar analiz edildi. Hastalar bilgisayarlı tomografi taramalarına göre Stanford Tip A veya B diseksiyonları olarak sınıflandırıldı. Ayrıca hastalar sağkalım açısından karşılaştırıldı. Seksen sekiz hastada akut aort diseksiyonu yapıldı ve ortalama yaş $61,90 \pm 12,67$ idi. Stanford Sınıflamasına göre 68 hastada Tip A diseksiyon saptandı. Tip A'da mental durum değișikliği ve senkop daha fazla idi ( $p=0,003$ ve $\mathrm{p}=0,001)$. Tip A'da bilateral kol tansiyon farkı daha fazlaydı $(\mathrm{p}=0,007)$. Tip A'da kan ürünü kullanımı ve endotrakeal entübasyon sayısı istatistiksel olarak daha fazla idi $(\mathrm{p}=0,002$ ve $\mathrm{p}=0,005)$. Ölüm riski bilateral kol tansiyon farkı olan hastalarda $3,5 \mathrm{~kat}$, acil serviste kardiyak arrest gelișenlerde 5,07 kat, kan ürünü transfüzyonu olanlarda 5,41 kat daha fazlaydı. [sırasıyla OR:3,50; (CI \%95 1,36-8,94) p=0,009, OR: 5,07; (CI \%95 1,18-21,39) p=0,027 ve OR: 5,41; (CI \%95 1,97-14,78) p=0,001]. Acil serviste ve hastanede ölüm oranları sırasıyla \%12,5 ve \%61,4 idi. Aort diseksiyonları, acil serviste yönetimin çok önemli olduğu klinik durumlar olmaya devam edecektir. AD'nin atipik prezentasyonu ve hastalığın doğası tanıda gecikmelere neden olmaktadır. Senkop ve mental durum değişikliği ile başvuran hastalarda $\mathrm{AD}$ ön planda düşünülmelidir. Klinik bir şüphe olduğunda, aortun bilgisayarlı tomografi ile görüntülemesi hızlı bir şekilde yapılmalıdır.

Anahtar Kelimeler: Aort diseksiyonu; Acil servis, Stanford sınıflaması 


\section{Introduction}

Aortic dissection (AD) is a life-threatening condition that can be seen in the emergency department (ED). Even if optimal conditions are met mortality of the disease is around $27 \%$ (1). Relatively atypical process of the disease which can mimic other critical conditions makes it harder to diagnose. The number of centers that are not equipped to accurately treat the condition being a lot and high mortality even after the correct diagnosis are handicaps that emergency physicians encounter. Prevalence as low as 3,5/100.000 also makes the diagnosis harder $(2,3)$. The use of scoring systems is inevitable due to different clinical syndromes that patients complain about and different physical examination findings but still, there are delays in diagnosis which makes mortality percentages rise (4-6).

$\mathrm{AD}$ is the separation of the adventitial layer due to weakness and disruption of the intimal layer. It is thought to be the result of abnormal blood flow due to hemodynamic stress factors, connective tissue disorders, or anatomic anomalies such as a bicuspid aortic valve. Prognosis and diagnosis are largely dependent on the anatomic location of the dissection. Stanford classification which is derived from the anatomic location is used widely. Most of the dissections are type A and these are typically associated with higher mortality. It is shown that surgical repair reduces mortality rates in type A dissections $(7,8)$.

Still, the most important diagnostic tool is computed tomography angiography (CTA) $(9,10)$. While there are lots of studies for use of point-of-care-ultrasonography (POCUS) in EDs, the most important step for the process is suspicion of the disease. Problems may occur due to transthoracic window images and the user-dependent results of POCUS $(11,12)$.

The disease is classified as hyperacute if it started in the last 24 hours, acute if 1-14 days, subacute if 15-90 days, and chronic if it existed for more than 90 days. Hyperacute dissections are encountered with more intense clinical presentation and have higher mortality (13).
The primary outcome of our study was to determine ED presentations and factors that influence the diagnostic process of $\mathrm{AD}$ patients. The secondary outcome was to determine ED and in-hospital mortalities of the patients who had been included.

\section{Materials and Methods}

This study is a single-centered retrospective observational one that is conducted using the data of patients who had been admitted to the ED of a third-level university hospital between the 1st of January 2011 and 1st of April 2021. Our hospital is a third-level center that has onsite non-surgical and surgical specialists who provide healthcare for 24 hours with approximately 100.000 ED admissions annually. The study is started after the approval of the ethics committee.

Patients who had ICD-10 codes for AD (I71 and addendums) in their digital files were analyzed retrospectively. We classified patients as hyperacute, acute or chronic according to the current literature. CTA Scans were evaluated and false diagnoses (the ones who had ICD-10 code in their file mistakenly) were excluded. Only the first admission was included if there were repeated admissions. Patients were categorized into Stanford Type A or B dissections according to their computerized tomography scans. The scans were evaluated by an emergency physician and a cardiovascular surgeon (MEC, AS). Also, another categorization was made in terms of survival and these two groups were compared to each other.

Demographics, comorbidities, presenting symptoms, vital parameters, whether they were referred from another center, bilateral arm pressure differential, computed tomography time, complete blood count, biochemistry panel, cardiac enzymes, arterial or venous blood gases, ED outcomes, and inhospital outcomes of the included patients were evaluated. ED outcomes of Type A and Type B groups were classified as hospitalization, exitus, or referral to another hospital. 


\section{Statistical Analysis}

Continuous data were given as Mean \pm Standard Deviation, data that do not fit into normal distribution were given as Median [25.-75. interquartile range], categorical data were given as a percentage (\%). We used Shapiro Wilk's test to determine if the data fit into a normal distribution. Student-t test was used for data that fit into normal distribution and the Mann-Whitney $U$ test is used when two groups did not. Cross-tables were analyzed with Pearson Chi-Square and Fisher Exact Chi-Square tests. Logistical regression analysis was used to determine risk factors. We used the IBM SPSS Statistics 21.0 program (IBM Corp. Released 2012. IBM
SPSS Statistics for Windows, Version 21.0. Armonk, NY: IBM Corp.) to run the analyses.

\section{Results}

Ninety-one patients got $\mathrm{AD}$ diagnosis in the ED. Three of them were excluded because they were transection cases that developed after trauma. Eight patients out of eighty-eight remaining did not have CTA imaging either because they were referred from other centers which had scanning images with them, or they developed cardiac arrest in ED before any imaging. The mean age was $61.90 \pm 12.67$ years. Demographics, comorbidities, presenting symptoms, time onset of symptoms, and referral reasons from other centers were given as a table (Table 1).

Table 1. The demographic data and general characteristics of the patients according to Stanford classification

\begin{tabular}{lllll}
\hline & Total $(\mathrm{n}=88)$ & Type A $(\mathrm{n}=68)$ & Type B (n=20) & P \\
\hline Age, years & $61.90 \pm 12.56$ & $62.24 \pm 12.63$ & $60.75 \pm 12.57$ & \\
Female, $\mathrm{n}(\%)$ & $20(22.7)$ & $15(22.1)$ & $5(25.0)$ & 0.768 \\
Chief Complaint, $\mathrm{n}(\%)$ & & & \\
Chest pain & & $28(41.2)$ & $8(40.0)$ & 0.925 \\
Back pain & $36(40.9)$ & $18(26.5)$ & $8(40.0)$ & 0.244 \\
Dyspnea & $26(29.5)$ & $7(10.3)$ & $3(15.0)$ & 0.689 \\
Syncope & $10(11.4)$ & $26(38.2)$ & 0 & 0.001 \\
Altered mental statis & $26(29.5)$ & $22(32.4)$ & 0 & 0.003 \\
Abdominal pain & $22(25.0)$ & $11(16.2)$ & $5(25.0)$ & 0.509 \\
Lateralizing deficitis & $16(18.2)$ & $11(16.2)$ & 0 & 0.063 \\
Complaint time, hours $[\mathrm{IQR}]$ & $11(12.5)$ & $2.00[0.63-10.00]$ & $4.00[2.00-7.50]$ & 0.064 \\
Medical history, $\mathrm{n}(\%)$ & $2.00[1.00-9.50]$ & & & \\
Hypertension & & $42(61.8)$ & $10(50.0)$ & 0.347 \\
Diabetes mellitis & $52(59.1)$ & $12(17.6)$ & $4(20.0)$ & 0.753 \\
Coronary artery disease & $16(18.2)$ & $15(22.1)$ & $6(30.0)$ & 0.552 \\
Heart faihure & $21(23.9)$ & $7(10.3)$ & $3(15.0)$ & 0.689 \\
Aortic disease & $10(11.4)$ & $6(8.8)$ & $3(15.0)$ & 0.419 \\
Renal faihure & $9(10.2)$ & $3(4.4)$ & $1(5.0)$ & 0.999 \\
\hline IOR: Interquartile range & $4(4.5)$ & & &
\end{tabular}

Seventy-eight patients were presented to the ED in hyperacute phase $(88,6 \%)$ and 10 patients were classified as acute $\mathrm{AD}(11,4 \%)$. None of the patients included were in chronic phase of the disease.

Vitals were analyzed in 84 patients, 4 patients either did not have vital parameters recorded or were brought to ED in cardiac arrest state. In terms of vital parameters, there was no statistically significant difference between Type A and Type B dissections. Median CTA obtaining time was 58:00 [34:13-97:00] minutes and there was no statistically significant difference between Type A and
Type $B$ dissections $(\mathrm{p}=0.396)$. Bilateral arm pressure differential, developing cardiac arrest in ED, use of blood products, use of inotropic agents, use of negative chronotropic agents and endotracheal intubation were higher in percentage in Type A group $(\mathrm{p}=0.007$, $\mathrm{p}=0.174, \mathrm{p}=0.002, \mathrm{p}=0.072, \mathrm{p}=0.047, \mathrm{p}=0.005$ respectively). While there is no statistically significant difference there is clinical significance in terms of developing cardiac arrest in ED and use of inotropic agents. Type A group also had lower hemoglobin and hematocrit, and higher creatinine levels in the laboratory results $(\mathrm{p}=0.017, \mathrm{p}=0.026, \mathrm{p}=0,008$ respectively) (Table 2 ). 
Table 2. Vital signs, ED management, and the laboratory findings of the patients according to the Stanford classification

\begin{tabular}{|c|c|c|c|c|}
\hline & Total $(\mathrm{n}=88)$ & Type A $(n=68)$ & Type B $(n=20)$ & $\mathrm{p}$ \\
\hline Vital signs, [IQR] & $\mathrm{n}=84$ & $\mathrm{n}=64$ & $\mathrm{n}=20$ & \\
\hline$S B P, m m H g$ & $110.0[90.0-146.0]$ & $100.0[80.0-149.5]$ & $120.0[100.0-140.0]$ & 0.140 \\
\hline$D B P, m m H g$ & $70.0[50.0-80.0]$ & $68.5[50.0-80.0]$ & $70.0[60.0-80.0]$ & 0.149 \\
\hline Pulse, rate & $86.0[75.3-94.0]$ & $83.0[75.0-93.5]$ & $88.0[81.0-95.8]$ & 0.224 \\
\hline $\mathrm{SpO} 2, \%$ & $94.0[90.0-96.0]$ & $94.0[90.0-96.0]$ & $95.0[93.3-96.0]$ & 0.095 \\
\hline BABP difference, $n(\%)$ & $36(40.9)$ & $33(48.5)$ & $3(15.0)$ & 0.007 \\
\hline $\begin{array}{l}\text { ED management, } n(\%) \\
\text { CT time, wijlises }(80 \\
\text { patients) }\end{array}$ & $58: 00$ [34:13-97:00] & $51: 00[34: 27-82: 00]$ & $63: 00[31: 00-116: 00]$ & 0.396 \\
\hline Arrest in the $E D$ & $15(17.0)$ & $14(20.6)$ & $1(5.0)$ & 0.174 \\
\hline Blood products & $35(39.8)$ & $33(48.5)$ & $2(10.0)$ & 0.002 \\
\hline Inotropic agents & $10(11.4)$ & $10(14.7)$ & 0 & 0.072 \\
\hline $\begin{array}{l}\text { Negative chronotropic } \\
\text { agents }\end{array}$ & $28(31.8)$ & $18(26.5)$ & $10(50.0)$ & 0.047 \\
\hline ETI & $20(22.7)$ & $20(29.4)$ & 0 & 0.005 \\
\hline \multicolumn{5}{|l|}{ Laboratory, [IQR] } \\
\hline Hemoglobim, g/dl & $13.95[12.43-15.10]$ & $13.50[12.25-14.80]$ & $15.10[12.85-16.58]$ & 0.017 \\
\hline Hematocrit, \% & $41.00[37.25-45.18]$ & $40.30[36.73-44.02]$ & $45.35[38.10-47.90]$ & 0.026 \\
\hline Creatinine, $\mathrm{mg} / \mathrm{dl}$ & $1.17[1.00-1.44]$ & $1.19[1.03-1.51]$ & $1.03[0.89-1.20]$ & 0.008 \\
\hline$B U N, m g / d l$ & $17.75[14.83-22.08]$ & $18.95[14.95-22.43]$ & $15.45[13.13-17.48]$ & 0.112 \\
\hline Troponin, $\mathrm{pg} / \mathrm{ml}$ & $20.0[11.0-36.5]$ & $22.00[11.0-40.0]$ & $11.0[7.8-11.5]$ & 0.065 \\
\hline pH & 7.33 [7.28-7.38] & $7.46[7.37-7.48]$ & $7.34[7.29-7.41]$ & $<0.001$ \\
\hline Lactate, mmoll & $3.60[2.55-5.70]$ & $2.30[1.58-4.13]$ & $3.50[2.35-5.05]$ & 0.056 \\
\hline
\end{tabular}

In our study troponin and lactate levels were higher; hemoglobin and $\mathrm{pH}$ levels were lower in the non-survivor group $(\mathrm{p}=0.044, \mathrm{p}=0.025$, $\mathrm{p}=0.041, \mathrm{p}=0.011$ respectively).

Forty-five patients were hospitalized and twenty-two of them had been operated on. The median operation time was $4.50[3.75-$ 40.50] hours. Type A group had the operation earlier in their stay $(p=0.027)$. ED outcomes did not had any statistically significant differences $(p=0.463)$ (Table 3). When all outcomes, ED or in-hospital, are accounted for Type A patients had a $69.1 \%$ exitus rate whereas Type B had 35\% ( $\mathrm{p}=0.006)$. Looking into the data of 32 patients who are referred to other centers, 10 of Type A and 4 of Type B could be discharged. $56.3 \%$ of these patients combined were declared dead in their referral centers which are slightly lower than our center (Table 3 ).

Table 3. ED and hospital outcomes of the patients.

\begin{tabular}{|c|c|c|c|c|}
\hline & Total $(\mathrm{n}=88)$ & Type A (n=68) & Type B $(n=20)$ & $\mathbf{p}$ \\
\hline \multicolumn{5}{|l|}{ ED Outcome n $(\%)$} \\
\hline Admission & $45(51.1)$ & $33(48.5)$ & $12(60.0)$ & 0.463 \\
\hline Exitus & $11(12.5)$ & $10(14.7)$ & $1(5.0)$ & \\
\hline Transfer to other center & $32(36.4)$ & $25(36.8)$ & $7(35.0)$ & \\
\hline \multicolumn{5}{|l|}{ Hospital outcome $\mathrm{n}(\%)$} \\
\hline Discharge & $22(25.0)$ & $16(23.5)$ & $6(30.0)$ & 0.006 \\
\hline Exitus. & $54(61.4)$ & $47(69.1)$ & $7(35.0)$ & \\
\hline
\end{tabular}

In total, $61.36 \%$ of patients who got an $\mathrm{AD}$ diagnosis died. The mean age for these patients was $65.41 \pm 11.13$ years and these patients were older than the survivors $(p=0.001)$. A significant rise in the risk of death was observed in patients who have presented with syncope or altered mental status [OR: 3.69; (CI 95\%:1.27-10.64); $\mathrm{p}=0.015$ and OR:5.61; (CI 95\% 1.60-19.36); $\mathrm{p}=0.005$ respectively] Other symptoms had no 
statistically significant differences. Initial systolic and diastolic blood pressures were lower in the non-survivor group $(\mathrm{p}=0.045$, $\mathrm{p}=0.038$ respectively) and the non-survivor group had more bilateral arm blood pressure differential in their presentation $(\mathrm{p}=0.009)$. Median CTA time was twenty-six minutes lesser in non-survivor group as 47:00 [31:3077:15] ( $\mathrm{p}=0.012)$. While this group had quicker diagnoses, the prognosis was worse as thirteen of the non-survivor group developed cardiac arrest during their ED stay while only two of the survivor group did $(p=0.027)$. The use of blood products and endotracheal intubation were also higher in the nonsurvivor group $(\mathrm{p}=0.001, \quad \mathrm{p}=0.003$ respectively) (Table 4). Patients who had bilateral arm blood pressure differential had 3.5-fold, who had developed cardiac arrest in ED had 5.07-fold, who got blood product transfusions had 5.41-fold more risk of death. [OR:3.50; (CI 95\% 1.36-8.94) $\mathrm{p}=0.009$, OR: 5.07; (CI 95\% 1.18-21.39) $\mathrm{p}=0.027$ and OR: 5.41; (CI 95\% 1.97-14.78) $\quad \mathrm{p}=0.001$ respectively].

Table 4. The demographic data, general characteristics, ED management, and laboratory findings of the patients according to survivor and non-survivor groups.

\begin{tabular}{|c|c|c|c|}
\hline & Survivor $(n=34)$ & Non-survivor $(n=54)$ & $\mathbf{p}$ \\
\hline Age, years & $56.32 \pm 12.84$ & $65.41 \pm 11.13$ & 0.001 \\
\hline Female, $\mathfrak{n}(\%)$ & $5(14.7)$ & $15(27.8)$ & 0.154 \\
\hline \multicolumn{4}{|l|}{ Chief Complaint, n $(\%)$} \\
\hline Syncope & $5(14.7)$ & $21(38.9)$ & 0.015 \\
\hline Altered mental statis & $3(8.8)$ & $19(35.2)$ & 0.005 \\
\hline Complaint time, hours [IQR] & $4.0[1.0-12.0]$ & $2.0[0.5-8]$ & 0.052 \\
\hline \multicolumn{4}{|l|}{ Vital signs, [IQR] } \\
\hline$S B P, m m H g$ & $120.00[100.00-142.50]$ & 100.00 [78.75-148.50] & 0.045 \\
\hline$D B P, m m H g$ & $70.00[60.00-82.00]$ & $60.00[48.75-77.00]$ & 0.038 \\
\hline Pulse, rate & $84.50[77.50-94.50]$ & $87.50[75.00-92.50]$ & 0.927 \\
\hline $\mathrm{SpO}, \%$ & $95.00[92.00-96.00]$ & $94.00[90.00-95.00]$ & 0.130 \\
\hline BABP difference, $\mathrm{n}(\%)$ & $8(23.5)$ & $28(51.9)$ & 0.009 \\
\hline \multicolumn{3}{|l|}{$\begin{array}{l}\text { ED management, } \mathrm{n}(\%) \\
\text { CT time }\end{array}$} & 0.012 \\
\hline Arrest & $2(5.9)$ & $13(24.1)$ & 0.027 \\
\hline Blood products & $6(17.6)$ & $29(53.7)$ & 0.001 \\
\hline Inotropic agents & $2(5.9)$ & $8(14.8)$ & 0.305 \\
\hline Negative chronotropic agents & $14(41.2)$ & $14(25.9)$ & 0.135 \\
\hline EII & $2(5.9)$ & $18(33.3)$ & 0.003 \\
\hline \multicolumn{4}{|l|}{ Laboratory, [IQR] } \\
\hline Hemoglobin, goll & $14.45[13.28-15.55]$ & $13.50[11.88-15.00]$ & 0.041 \\
\hline Hematocrit, \% & $42.15[38.85-46.25]$ & $40.85[36.08-44.65]$ & 0.219 \\
\hline Creatinine, $m g / d l$ & $1.09[0.96-1.50]$ & 1.19 [1.08-1.39] & 0.456 \\
\hline$B U N, m g / d l$ & $16.00[13.45-21.15]$ & $18.60[15.05-22.28]$ & 0.408 \\
\hline Troponin, pg/ml & $12.0[7.0-30.0]$ & $22.0[12.0-41.0]$ & 0.044 \\
\hline pH & $7.41[7.34-7.44]$ & $7.33[7.29-7.38]$ & 0.011 \\
\hline Lactate, mmoll & $2.70[1.80-3.40]$ & $4.00[2.45-6.85]$ & 0.025 \\
\hline
\end{tabular}

\section{Discussion}

We assessed the ED processes and mortalities of patients in our study. In ADs, especially in Type A ADs, delays in diagnosis effects outcome highly. Every passing hour without a definitive diagnosis and initiation of treatment contributes to mortality around $1-2 \%(14)$. Our median CTA obtaining time was 58:00 [34:13-97:00] minutes. This high CTA obtaining time might have contributed to high mortality rates since by nature there is also a time gap between patient getting the CT Scan and initiation of treatment. We found that mortality rates were higher in patients who have presented to the ED with syncope, altered mental status, and who had bilateral arm blood pressure differential in their physical examination. Patients whom whom blood products were used also had higher mortality rates. The mean age of patients was $61.90 \pm 12.56$. Patients in a study which was conducted in Turkey had a mean age of $62.8 \pm 13.4$ years $(15)$. In another study which was conducted by Mehta et al. mean age was $61.8 \pm 14.2$ (16). The International Registry of Acute Aortic Dissection (IRAD) study group also found the mean age to be $61.8 \pm 14.4$ similarly (7). We see that this clinical condition emerges more in the 7th decade of 
life and our study confirmed the same results. In this age period, cerebrovascular diseases or acute coronary syndromes which can present with syncope, altered mental status, and/or chest pain has faster imaging and diagnosis times while AD patients remain to get delayed diagnoses(17). While incidences for those diseases are higher, emergency physicians should also have high clinical suspicion for $\mathrm{AD}$ while providing for patients who have presented with these symptoms and use clinical decision tools and POCUS to improve diagnostic times since it affects survival rates vastly $(11,18)$.

Earlier studies showed that ADs have a higher incidence among men. Olsson et al found that aortic disease (dissection and aneurysm combined) is seen less in women (38\%) (19). DiEusanio et al had $30.9 \%$ women in their study (20). Our study's results showed that $22.7 \%$ of patients were female. Sociodemographic traits might have played a role in this difference.

Chest pain as a chief complaint was noted in $40.9 \%$ of patients which makes it the highest rate in our study. Back pain followed it with $29.5 \%$. IRAD study shows that the most frequent chief complaint was chest pain $70.6 \%$, pain in abdomen and back followed it with $58.5 \%$ and $48.5 \%$ respectively (7). Another study showed that $90.8 \%$ of the pains were started abruptly and $23.1 \%$ of them were classified as 'most intense pain of patients' life (20). ESC guidelines also state that the most frequent symptom is chest pain with an $80 \%$ rate and similarly followed by abdominal pain and back pain (10). Syncope was seen in $15 \%$ of patients in Type A patients and $5 \%$ in Type B patients. In terms of chief complaints, we included syncope, altered mental status, and lateralizing deficits. This might have affected the different rates that are seen in our study. Our hospital is a stroke center in the area and emergency medical services (EMS) tend to choose our hospital as a destination for those symptoms to reduce intervention times in stroke. This also might be the cause for lesser incidence of chest, abdominal and back pain and higher incidence in syncope and other neurological symptoms.
A meta-analysis that was conducted in 2017 stated hypertension (HT) as a weak predictor of the disease (4). Different studies suggest hypertension as the most important risk factor for the disease $(7,21,22)$. We have found that $59 \%$ of our patients had hypertension in their medical history. This was in line with current literature. In a 2018 study by Howard et al hypertension as a risk factor was established again while it was seen more in Type A patients (23). We found no statistically significant difference in terms of hypertension prevalence between the Type A group's and Type B group's medical history.

Type A patients had a worse prognosis than Type B patients as demonstrated by their laboratory parameters, use of negative chronotropic agents, endotracheal intubation rates, and exitus rates. Current literature suggests that Type A patients' risk of death is higher. Our study's findings were in line with that $(21,24)$.

It is shown that troponin and hemoglobin levels have prognostic value in cardiovascular diseases, mostly in acute coronary syndromes and congestive heart failure $(25,26)$. There are studies on Troponin in AD which suggest no relation to in-hospital mortality of AD patients $(27,28)$. Only one study was found in our literature review about hemoglobin levels which has evaluated the pre-operative hemoglobin levels and it was conducted in Type B patients (29). We included all AD patients and found out that lower hemoglobin levels are associated with a lower survival rate $(\mathrm{p}=0.041)$. Lactate and $\mathrm{pH}$ have a known prognostic value for in-hospital mortality among various conditions especially in critically ill patients (30). While there are multiple studies about post-operative serum lactate levels for prognosis in AD patients, we have found only one study that had examined the pre-operative lactate levels. Bennett et al looked into the pre-operative serum lactate levels in $\mathrm{AD}$ patients and found it to be related to mortality (31). However, due to the study design, patients' laboratory values were obtained right before the surgery, and only the type A patients were included. We evaluated our patients' presenting lactate levels, regardless of their type, and found it to be related to death rates $(p=0.025)$. More studies 
about this topic are needed but our study suggests presenting lactate levels can be used for prognosis in all types of $\mathrm{AD}$.

We also found that blood products are used more often in ED in type A patients. There is a study for in-operative use of blood products, associating it with higher mortality (32). To our knowledge use of blood products and mortality relation in ED has not been studied before. Since almost half of patients with Type A AD diagnosis had transfusions, it might be wise to order cross-match tests as one of the initial laboratory tests for patients with suspected $\mathrm{AD}$. This topic requires further studies.

Exitus rates among our patients were higher than previous studies both overall (61.4\%) and in different types, type A being highest (69.1\% in Type A and 35\% in Type B). IRAD study puts death rates among AD patients as $27.4 \%, 22 \%$ in type A patients with a decrease in trend, and $13 \%$ in type B patients (7). Because this was a retrospective study, identifying the cause for this almost 2.5 -fold more death rate could not be done.

\section{Limitations}

Our study was a single-centered retrospective study which might have affected the demographics of the patients and results might not be generalized. Relatively shorter times for referring to another center than acquiring proper equipment for these patients might have biased the study towards referral patients having less mortality. This was a retrospective study with no way of testing the skills of physicians who cared for these patients.

\section{REFERENCES}

1. Ankel F. Aortic dissection. In: Marx JA, Hockberger RS, Walls RM, et al, editor. Rosen's Emergency Medicine: Concepts and Clinical Practice. 7th ed. Philadelphia, PA: Mosby Elsevier Publishing; 2010. p. 1088-92.

2. Clouse WD, Hallett JW, Schaff HV, Spittell PC, Rowland CM, Ilstrup DM, et al. Acute aortic dissection: population-based incidence compared with degenerative aortic aneurysm rupture. Mayo Clin Proc. 2004 Feb;79:176-80.

\section{Conclusion}

Aortic dissection will stay as important clinical condition which management in ED is crucial. Our study revealed that our mortality rates are seriously higher than expected. This might be explained by the nature of the study as most patients who have presented to ED had hyperacute $\mathrm{AD}$ which is expected to have higher mortality. But still, there is room for improvements both in our clinic and in other referral centers. While being lower in the nonsurvivor group, we found out that our CTA times are high which make diagnosis times not optimal. Aortic dissections might indeed mimic the symptoms of other diseases with higher incidence (acute coronary syndromes and cerebrovascular diseases to name a few) but still, all emergency physicians should be encouraged to initiate the diagnostic tests earlier on patients with high clinical suspicion of aortic dissections. To reduce the intervention time, emergency medical services personnel should be coordinated to bypass local health centers and refer patients directly to centers that have the necessary equipment for diagnosis and/or treatment for ADs as well. For example, acute coronary syndromes and cerebrovascular diseases are referred directly to selected centers this way. A similar approach could be adopted for $\mathrm{AD}$ as well. Also, coordination between hospitals that are in a local area that has the means to treat the disease should be improved for better outcomes. This would reduce repeated diagnostic tests which adds the time for intervention, radiation exposure in cases of repeated CTAs, and healthcare costs.
3. Cantrill SV, Brown MD, Burton JH, Diercks DB, Gemme SR, Gerardo CJ, et al. Clinical Policy: Critical Issues in the Evaluation and Management of Adult Patients With Suspected Acute Nontraumatic Thoracic Aortic Dissection. Annals of Emergency Medicine. 2015;65:32-42.e12.

4. Ohle R, Kareemi HK, Wells G, Perry JJ. Clinical Examination for Acute Aortic Dissection: A Systematic Review and Meta-analysis. Acad Emerg Med. 2018 ;25:397-412. 
5. Nazerian P, Ascione G, Castelli M, Capretti E, Ranaldi F, Bonaccorsi L, et al. Additional risk factors for evaluation of suspected acute aortic syndromes in the emergency department. Acad Emerg Med. 2021: 22;

6. Nazerian P, Mueller C, Soeiro A de M, Leidel BA, Salvadeo SAT, Giachino F, et al. Diagnostic Accuracy of the Aortic Dissection Detection Risk Score Plus D-Dimer for Acute Aortic Syndromes: The ADvISED Prospective Multicenter Study. Circulation. $2018 ; 137: 250-8$.

7. Hagan $\mathrm{PG}$, Nienaber CA, Isselbacher EM, Bruckman D, Karavite DJ, Russman PL, et al. The International Registry of Acute Aortic Dissection (IRAD): new insights into an old disease. JAMA. $2000: 16 ; 283: 897-903$.

8. Lombardi JV, Hughes GC, Appoo JJ, Bavaria JE, Beck AW, Cambria RP, et al. Society for Vascular Surgery (SVS) and Society of Thoracic Surgeons (STS) Reporting Standards for Type B Aortic Dissections. Ann Thorac Surg. 2020 ;109:959-81.

9. JCS Joint Working Group. Guidelines for diagnosis and treatment of aortic aneurysm and aortic dissection (JCS 2011): digest version. Circ J. 2013;77:789-828.

10. Erbel R, Aboyans V, Boileau C, Bossone E, Bartolomeo RD, Eggebrecht H, et al. 2014 ESC Guidelines on the diagnosis and treatment of aortic diseases: Document covering acute and chronic aortic diseases of the thoracic and abdominal aorta of the adult. The Task Force for the Diagnosis and Treatment of Aortic Diseases of the European Society of Cardiology (ESC). Eur Heart J. $2014 ; 35: 2873-926$.

11. Sobczyk D, Nycz K. Feasibility and accuracy of bedside transthoracic echocardiography in diagnosis of acute proximal aortic dissection. Cardiovasc Ultrasound [Internet]. 2015 Mar 25 [cited 2021 Apr 26];13. Available from: https://www.ncbi.nlm.nih.gov/pmc/articles/PMC4 396118/

12. Wang Y, Yu H, Cao Y, Wan Z. Early Screening for Aortic Dissection With Point-of-Care Ultrasound by Emergency Physicians: A Prospective Pilot Study. J Ultrasound Med. 2020 ;39:1309-15.

13. Soar J, Böttiger BW, Carli P, Couper K, Deakin $\mathrm{CD}$, Djärv $\mathrm{T}$, et al. European Resuscitation Council Guidelines 2021: Adult advanced life support. Resuscitation. 2021;161:115-51.

14. Akin I, Nienaber CA. Prediction of aortic dissection. Heart. $2020 ; 106: 870-1$.

15. Ersel M, Aksay E, Kiyan S, Bayraktaroglu S, Yuruktumen A, Ozsarac M, et al. Can D-dimer testing help emergency department physicians to detect acute aortic dissections? Anadolu Kardiyol Derg. 2010; 1;10:434-9.

16. Mehta RH, O'Gara PT, Bossone E, Nienaber CA, Myrmel T, Cooper JV, et al. Acute type A aortic dissection in the elderly: clinical characteristics, management, and outcomes in the current era. $J$ Am Coll Cardiol. 2002;40:685-92.

17. Jauch EC, Saver JL, Adams HP, Bruno A, Connors JJ (Buddy), Demaerschalk BM, et al. Guidelines for the Early Management of Patients With Acute Ischemic Stroke. Stroke. 2013 ;44:870-947.
18. Meredith EL, Masani ND. Echocardiography in the emergency assessment of acute aortic syndromes. European Journal of Echocardiography. $2009 ; 10: 131-9$.

19. Olsson C, Thelin S, Ståhle E, Ekbom A, Granath F. Thoracic aortic aneurysm and dissection: increasing prevalence and improved outcomes reported in a nationwide population-based study of more than 14,000 cases from 1987 to 2002. Circulation. 2006;114:2611-8.

20. Di Eusanio M, Trimarchi S, Patel HJ, Hutchison S, Suzuki T, Peterson MD, et al. Clinical presentation, management, and short-term outcome of patients with type A acute dissection complicated by mesenteric malperfusion: observations from the International Registry of Acute Aortic Dissection. J Thorac Cardiovasc Surg. 2013;145:385-390.e1.

21. Gawinecka J, Schönrath F, von Eckardstein A. Acute aortic dissection: pathogenesis, risk factors and diagnosis. Swiss Medical Weekly [Internet]. 2017 Aug 25 [cited 2021 Jun 18];147(3334). Available from: https://smw.ch/article/doi/smw.2017.14489

22. Akutsu K. Etiology of aortic dissection. Gen Thorac Cardiovasc Surg. $2019 ; 67: 271-6$.

23. Howard DP, Banerjee A, Fairhead JF, Perkins J, Silver LE, Rothwell PM. Population-based study of incidence and outcome of acute aortic dissection and pre-morbid risk-factor control: 10year results from the Oxford Vascular Study. Circulation. 2013 21;127:2031-7.

24. Sievers H-H, Rylski B, Czerny M, Baier ALM, Kreibich M, Siepe M, et al. Aortic dissection reconsidered: type, entry site, malperfusion classification adding clarity and enabling outcome prediction. Interact Cardiovasc Thorac Surg. 2020 ;30:451-7.

25. Kozinski M, Krintus M, Kubica J, Sypniewska G. High-sensitivity cardiac troponin assays: From improved analytical performance to enhanced risk stratification. Crit Rev Clin Lab Sci. 2017 ;54:143-72.

26. Shah KS, Maisel AS, Fonarow GC. Troponin in Heart Failure. Heart Fail Clin. 2018 ;14:57-64.

27. Vagnarelli F, Corsini A, Bugani G, Lorenzini M, Longhi S, Bacchi Reggiani ML, et al. Troponin T elevation in acute aortic syndromes: Frequency and impact on diagnostic delay and misdiagnosis. Eur Heart J Acute Cardiovasc Care. 2016 ;5:6171.

28. Bonnefoy E, Godon P, Kirkorian G, Chabaud S, Touboul P. Significance of serum troponin I elevation in patients with acute aortic dissection of the ascending aorta. Acta Cardiol. 2005 ;60:16570 .

29. Gao Z, Qin Z, An Z, Hou C, Wang L, Jin J. Prognostic Value of Preoperative Hemoglobin Levels for Long-Term Outcomes of Acute Type B Aortic Dissection Post-thoracic Endovascular Aortic Repair. Front Cardiovasc Med [Internet]. 2020 Nov 5 [cited 2021 Jun 18];7. Available from: https://www.ncbi.nlm.nih.gov/pmc/articles/PMC7 693721/

30. Cevik AA, Dolgun H, Oner S, Tokar B, Acar N, Ozakin E, et al. Elevated lactate level and shock index in nontraumatic hypotensive patients 
presenting to the emergency department. Eur $J$ Emerg Med. 2015;22:23-8.

31. Bennett JM, Wise ES, Hocking KM, Brophy CM, Eagle SS. Hyperlactemia Predicts Surgical Mortality in Patients Presenting With Acute Stanford Type-A Aortic Dissection. $J$ Cardiothorac Vasc Anesth. 2017;31:54-60.

32. Sultan I, Bianco V, Aranda-Michel E, Kilic A, Serna-Gallegos D, Navid F, et al. The use of blood and blood products in aortic surgery is associated with adverse outcomes. J Thorac Cardiovasc Surg. 2021 Mar 15;

๑Copyright 2021 by Osmangazi Tıp Dergisi - Available online at tip.ogu.edu.tr $\odot$ Telif Hakkı 2021 ESOGÜ Tıp Fakültesi - Makale metnine dergipark.org.tr/otd web sayfasından ulaşılabilir 